\title{
Küçük Hidrolik Santrallerde Kapasite Faktör Analizi ve Giresun Özelinde Bir Uygulama
}

\author{
Capacity Factor Analysis in Small Scale Hydropower Plants and a Practice Specific to \\ Giresun
}

Uğur SERENCAM*

Bayburt Üniversitesi, Mühendislik Fakültesi, İnşaat Mühendisliği Bölümü, 69000, Bayburt

• Geliş tarihi / Received: 10.04.2019 • Düzeltilerek geliş tarihi / Received in revised form: 05.07.2019 • Kabul tarihi / Accepted: 08.07.2019

\begin{abstract}
$\ddot{O ̈ z}$
Enerji, minimum ölçekte canlı bedeninden büyük ölçekte sanayi tesislerine kadar hayatın her alanında sosyal ve ekonomik sürdürülebilirliğin temel yapı taşıdır. Sanayileşmedeki gelişim sürecini hızla artıran Türkiye'de, enerji ihtiyacı büyük ölçüde ithal fosil kaynaklardan sağlanmaktadır. Ancak özellikle son yıllarda artan çevre bilinci, ekonomik ve stratejik gerekçelerle, enerji açığının bir kısmının yerli, temiz ve güvenilir kaynak olan hidroelektrik santrallerden karşılamasına büyük önem verilmiştir. Ülkemizde 2017 yılında toplam olarak $295511 \mathrm{GWh}$ elektrik üretilmiş olup, bunun $41368 \mathrm{GWh}$ 'lık miktarını (\%14) büyük hidrolik santraller ve $17082 \mathrm{GWh}$ 'lık miktarını da $(\% 5,78)$ küçük hidrolik santraller karşılamıştır. Bu çalışmada, Türkiye'de, artan enerji maliyetlerinin düşürülmesine yönelik çalışmalara küçük hidroelektrik santrallerin (KHS) katkısı irdelenmiş ve Giresun özelinde kapasite faktör analizi yapılmıştır. Bu sonuçlara göre Rezervuar alanı bulunmayan ve benzer özelliklerdeki hidroelektrik santrallerde, kapasite faktörü arttıkça santral yatırımının geri dönüş süresinin kısaldığı sonucuna ulaşılmıştır.
\end{abstract}

Anahtar kelimeler: Enerji, Hidrolik Elektrik Enerjisi, Kapasite Faktör Analizi, Küçük Hidrolik Santraller

\begin{abstract}
Energy is the fundamental element of social and economic sustainability in every aspect of life, from the smallest living body to large scale industrial facilities. In Turkey rapidly increasing industrial development process lead to extensive energy demand, which is met largely from imported fossil sources. Especially in recent years, as a result of increasing environmental awareness and economic and strategic reasons, a portion of the energy deficit is fed from, clean and reliable hydroelectric power plants with great importance. In our country, a total of 295511 GWh electricity was produced in 2017. About $41368 \mathrm{GWh}(14 \%)$ of the total amount was generated by large hydraulic plants and 17082 GWh (5.78\%) by small hydraulic plants. In this study, small hydroelectric power (SHP) stations are considered to reduce the increasing energy cost and for this purpose SHP in Giresun are analyzed leading to private additives in the capacity factor analysis. According to the results it is possible to conclude that thetime of power plant investment is shortened as the capacity factor increases in hydroelectric power plants.
\end{abstract}

Keywords: Energy, Hydraulic Electrical Energy, Capacity Factor Analysis, Small Hydraulic Plants

*Uğur SERENCAM; userencam @bayburt.edu.tr; Tel: (0458) 21111 52; orcid.org/0000-0002-5910-3667 


\section{Giriş}

Türkiye'de, hızlı nüfus artışı, gelişen ekonomi ve büyüyen sanayi yatırımlarına bağlı olarak enerji talebi hizla artmaktadır. Bu durum kisitl yeralt1 ve yerüstü kaynaklarına sahip ülkede enerji açığı sorununu ortaya çıkartmaktadır. İhtiyaç duyulan enerjinin temini için çeşitli seçenekler aranarak enerji maliyetlerini düşürmek ve belirli ülkelere bağımlılığı azaltmak için tedarik yollarında çeşitlendirici önlemler alınmaktadır. Ülkemizde 2016 y1lı itibariyle tüketilen 136,230 bin ton petrol eşdeğeri (ktoe) enerjinin sadece \%26'sını (35,374 ktoe) kendi öz kaynaklarından tedarik ermektedir. Aradaki 100,856 ktoe miktarındaki enerji açığı dış kaynaklardan temin edilmektedir. İthal edilen enerjinin \%29,36's1 petrol, \%27,9'u doğalgaz, \%16.8'i taş kömürü gibi fosil kaynaklardır. Enerji temininde yaklaşık \%70 oranında dışa bağımlı olan Türkiye artan ihracat gelirlerinin önemli bir kısmını ithal edilen enerjiye harcamaktadır. Enerjide dışa bağımlılığın yüksek olmas1, ithalat ve ihracat dengesini olumsuz etkilemekte, bütçe açıklarına meydan vermesinin yanında stratejik olarak da bağımlılığa neden olarak uluslararası karar mekanizmalarında ülkenin elini zayıflatmaktadır. Özellikle, güçlü enerji kaynakları olan ülkeler bu üstünlüklerini politik faydalara dönüştürmek için sürekli bir çaba içerisinde olmaktadırlar. $\mathrm{Bu}$ nedenlerle fosil kaynakların kısıtlı olduğu ülkemizde hidrolik potansiyelin değerlendirilmesine büyük önem verilmektedir. Hidrolik enerji kaynaklarının yenilenebilir olması, tesis kurulumunda makine ve teçhizatın az olması nedeni ile işletme ve bakım masraflarının diğer enerji santrallerine göre çok daha az olması, enerji üretim aşamalarının hiç birinde çevreye zararlı bir gaz ve atığın bırakılmaması ve en önemlisi de dışa bağımlılığı azaltarak ülkenin stratejik üstünlüğüne katk1 sağlamas1 gibi nedenlerle güvenilir enerji olan hidroelektrik enerjiye özellikle son yıllarda büyük önem verilmektedir (Ürker ve Çobanoğlu, 2017; Yuksel, 2013; Koralay vd., 2018).

Türkiye'de özellikle son yıllarda enerjide dişa bağımlılığı azaltma çalışmaları çerçevesinde kurumsal ve yasal düzenlemeler yapılarak yenilenebilir enerji yatırımlarına önemli teşvikler verilmiştir. $\mathrm{Bu}$ çalışmalar neticesinde önemli ithalat kalemlerinden olan kömür ve doğalgazı yakıt olarak kullanan santrallerin kurulu güç içerisindeki payı 2017 Mayıs itibarıyla 2016 yılına göre düşürülmüsş, ortaya çıkan enerji açığı büyük oranda yenilenebilir öz kaynaklardan giderilmiştir. Her ne kadar kömür ve doğalgaz kullanan santrallerin üretim kapasiteleri enerji ihtiyacına bağlı olarak artmış olsa bile toplam kurulu güç içerisindeki paylarında azalma olmuştur. Ülkemizde, kömür havzalarının değerlendirilerek daha verimli işletilmesine yönelik yapılan çalışmalar çerçevesinde termik santrallerde ithal kömürün payı düşürülerek yerli kömür kullanım oranının arttırıldığ1 gözlemlenmiştir (Tablo 1 ve 2) (Karagöl vd., 2016; URL-1, 2018).

Tablo 1. Türkiye'nin kaynaklara göre elektrik kurulu gücü [URL-1, 2018]

\begin{tabular}{lcc}
\hline BİRİNCİL ENERJİ KAYNAĞI & \multicolumn{2}{c}{ KURULU GÜÇ } \\
\cline { 2 - 3 } & $(\mathrm{MW})$ & Payı (\%) \\
\hline İthal Kömür & 8793.9 & \\
Taş Kömür \& Asfaltiti & 782.5 & \\
Linyit & 9090.1 & \\
Sivı Yakıt & 303.6 & \\
Çok Yakıtlı (Katı \& Sıvı) & 682.9 & \\
Çok Yakıtlı (Sıvı \& D. Gaz) & 3433.6 & \\
Doğalgaz & 23205.7 & \\
\hline Termik Toplam & 46292.1 & \\
\hline Biokütle & 634.2 & \\
Rüzgâr & 6516.2 & \\
Güneş & 3420.7 & \\
Barajlı HES & 19776.0 & \\
Akarsu HES & 7497.1 & 100.00 \\
Jeotermal & 1063.7 & \\
\hline Yenilenebilir Toplam & 38907.9 & \\
\hline GENEL TOPLAM & 85200 & \\
\hline
\end{tabular}

$\mathrm{Bu}$ çalışmada, ülkemizde özellikle son y1llarda kur artışına bağlı olarak artan enerji maliyetlerinin ülke ekonomisine vereceği zararın azaltılmasına yönelik olarak en önemli yerli kaynaklardan biri olan küçük hidroelektrik santrallerin (KHS) ulusal elektrik üretimine olan katkısı tartışılarak, 
hidroelektrik santral planlamalarında belirleyici kriterlerden biri olan kapasite faktör analizinin Giresun özelinde irdelenmesi yapılmaktadır.

Türkiye'nin elektrik üretimi, tüketimi ve hidroelektrik potansiyeline bakıldığında fosil yakıt rezervleri hızla azaldığ 1 görülmektedir. Dünya'da ise kömür yataklarının yaklaşık 100 yıl, petrol ve doğalgaz yataklarının ise yaklaşık 50 yıl sonra tükeneceği öngörülüyor. Rezervlerin kritik seviyelere düşmesi enerji arz güvenliğini tehdit etmekle kalmamaktadır. Fosil yakitların yakılması suretiyle enerji elde edilmesi sonucunda, hava kirliliği başta olmak üzere küresel ısınma ve iklim değişikliği gibi olumsuz etkiler de ortaya çıkmaktadır. Özellikle yenilenebilir enerji kaynaklarına artan ilgi dünyamızın geleceği adına umut vericidir. Yenilenebilir enerji kaynaklar1 arasında hidroelektrik, alternatifleri arasında kendisini benzersiz ve vazgeçilemez k1lan birtakım özelliklere sahip olması sebebiyle ön plana çıkıyor. Gerek işletme ve bakım maliyetlerinin düşüklüğü gerek pik taleplerin karşılanması noktasındaki başarısı gerekse enerjiyi depolamak gibi eşsiz bir özelliğe sahip olması hidroelektrik santralleri ayrıcalıklı bir yere taşımaktadır (Kaygusuz, 2018; URL-4, 2018; DSİ, 2017).

Türkiye'de 2016 y1lı sonu itibariyle toplam 273,387 milyar kWh elektrik üretilmiştir. $\mathrm{Bu}$ üretimde ilk sirayı, \%67,6'l1k bir orana karlık gelen 184,889 GWh'la termik santraller almaktadır. Bunu sırasıyla, \%24,6'sına karş11ık gelen 67,268 GWh'la hidroelektrik santrallerden ve \%7,8'ine karşıllik gelen 21,230 GWh'i de yenilenebilir enerji kaynaklarından sağlanmıştır. Yine aynı dönemde ülkemizin elektrik enerjisi tüketimi ise 278,3 milyar kWh'tır. Son 15 yılda, Türkiye'deki yıllık elektrik enerjisi tüketiminin artış hızı ortalaması \%5,4 seviyesinde gerçekleşmiştir. 2002 y1lındaki elektrik tüketimimiz 132,6 milyar kWh olup, bu tüketim miktarı hızlı sanayileşme ve kentleşmeye bağlı olarak 2016 yılında 2 kattan fazla artışla 278,3 milyar kWh'e ulaşmıştır. Aynı şekilde elektrik enerjisindeki talep artış oranı 2014'te \%4,4, 2015 'te \%3,3 iken, 2016 yılında \%4,7 olarak gerçekleşmiştir (Ürker ve Çobanoğlu, 2017).

Ülkemizde, özellikle 2009 y1lından sonra yenilenebilir enerji kaynaklarının değerlendirilmesine yönelik çalışmalar ve teşviklerle, 2016 yılı sonu itibarıyla toplam $273,387 \mathrm{GWh}$ olan elektrik üretimimizin içerisindeki yenilenebilir enerji payında önemli artışlar olmuştur. 2002 y1lında yenilenebilir enerji kaynaklarından rüzgâr ve jeotermal bazlı üretimimizin payı $153 \mathrm{GWh}$ 'la toplam üretimin yaklaşık \%0,1'ine karşıllı gelirken, bu oran 2016 yılı sonu itibarıla, özel önem verilip önemli yatırımlarla desteklenen güneş enerjisinin de dâhil olmasiyla birlikte 21,230 GWh miktarıla \%8 seviyesine ulaşmıştır. Türkiye'de 2016 yılı sonu itibarıyla toplam elektrik üretiminde $\% 67,6$ ile ilk sırada olan termik santrallerden üretilen elektrik enerjisinin \%33,74'lik kısmının ham maddesi kömür kaynaklı iken, \%32,1'lik kısmı ise önemli bir kısmı ithal edilen doğal gaz + LNG kaynaklıdır. (Şekil 1 ve 2).

Ülkede, yenilenebilir enerji kaynaklarından olan rüzgâr enerjisine yönelik verilen teşvikler neticesinde, rüzgâr santrallerinde üretilen elektriğin toplam üretimdeki pay1 2014 yılında $\% 3,4$ iken, bu oran 2016 y1l sonu itibariyle $\% 5,7$ 'ye ulaşmıştır. Ancak rüzgâr gücü ile kıyaslandığında, hidroelektrik santrallerin daha yüksek oranda elektrik üretme potansiyelleri vardır (ETKB, 2017; URL-2, 2018).

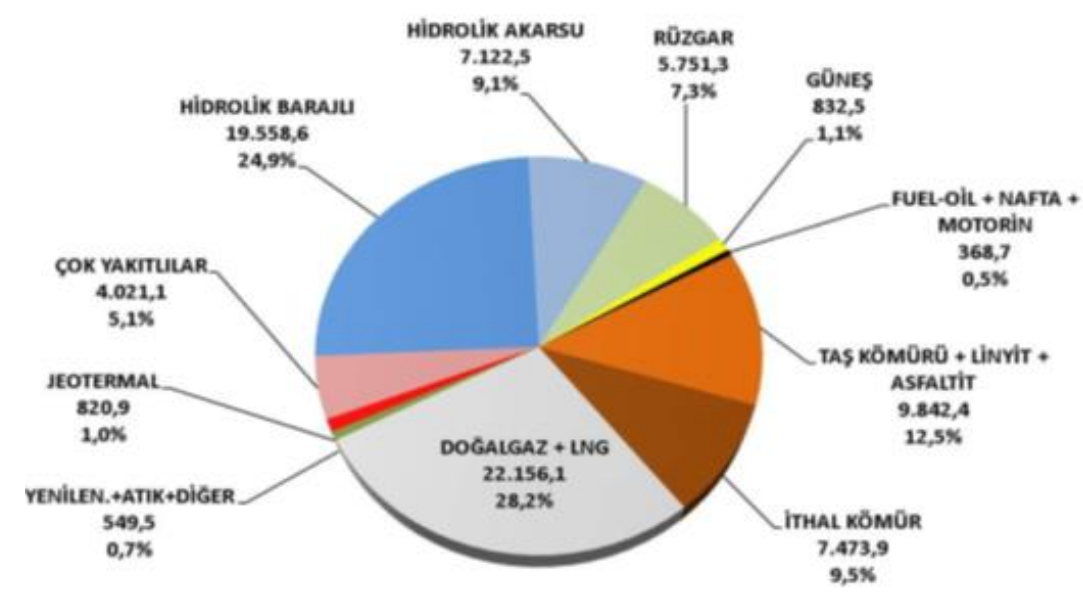

Şekil 1. Türkiye' de elektrik enerjisi kurulu gücü (URL-2, 2018) 


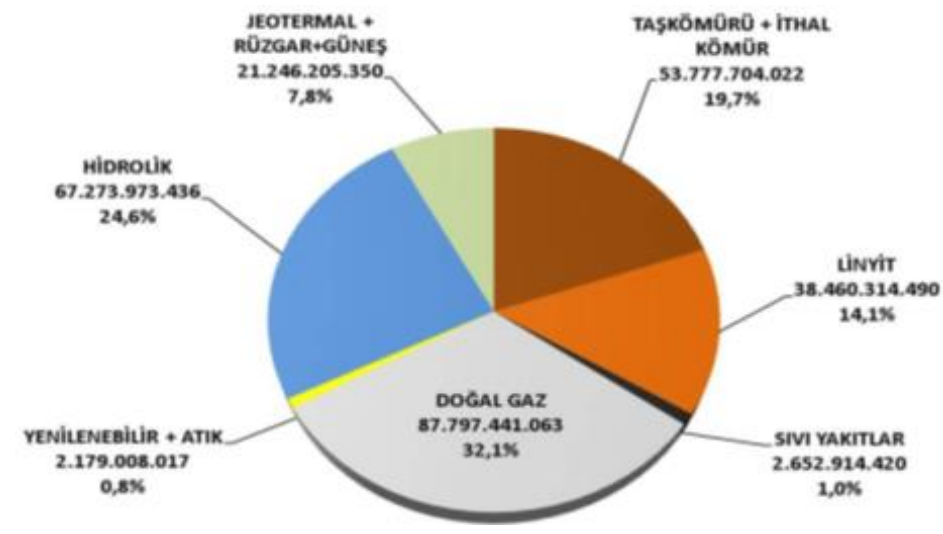

Şekil 2. Türkiye'de elektrik üretimi ve tüketimi (URL-2, 2018)

Türkiye'nin toplam ve teknik olarak yapılabilecek (fizibil) hidroelektrik potansiyel değerleri, sirasıyla 435 ve 215 TWh'tır; ekonomik olarak kullanılabilecek hidroelektrik potansiyeli ise DSİ tarafindan 128 TWh olarak tahmin edilmektedir. Türkiye'de bir tesisin fizibilitesi yapılırken kullanılan ölçütlerde ilk kurulum santral maliyetleri çok önemli bir ölçüt olarak değerlendirilmekte olup bu yaklaşım hidroelektrik santrallere yatırımc1 ilgisini azaltmaktadır. Fizibilite çalışmalarında, hidroelektrik santrallerin alternatif olarak termik santraller ön plana çıkmakta ancak termik santrallerin hammadde maliyetleri ve çevreye verdiği zarar göz ardı edilmektedir. Hidroelektrik santrallerin her ne kadar yüksek kurulum maliyetleri olsa da doğru bir vadi planlaması ve üretim yönetimi ile bu maliyetler kısa sürede amorti edilebilir. Çünkü hidroelektrik santrallerde üretilen enerjide yakıt sınırsız olup maliyeti yoktur. Bu özellik sürekli ekonomik dalgalanmaların etkisi altında bulunan ithal fosil yakıtlara göre çok önemli bir üstünlüktür. Ayrıca sıfır karbondioksit $\left(\mathrm{CO}_{2}\right)$ salınımı olan hidroelektrik santrallerde, güneş sınırlamaları, meteorolojik hava koşullarının da etkisi yok denecek kadar azdır. Termik santrallerde ise, kurulum dışı maliyetlerinin yanı sıra sebep oldukları çevre sorunlarının giderilmesi için gerekecek harcamalar, santral kurulumu için harcanan maliyetlerinin en az \%30'udur. Bu analiz ve kıyaslamalar yapılırken hidroelektrik santraller lehine hususlar yeterince dikkate alınmamaktadır. Ekonomik ve teknik fizibilite çalışmalarının sağlıklı yapılabilmesi durumunda, kurulum maliyetleri \%20-25 daha fazla olan hidroelektrik santraller bile termik santrallere göre daha fizibıl olacaktır. Buna santral dışı maliyetlerin de eklenmesi durumunda bu oran \%40-45 gibi belirgin bir düzeye çıkmaktadır. Bu yeni kriterlere göre Türkiye'nin yıllık ekonomik olarak kullanılabilecek hidroelektrik potansiyeli DSI'nin tahmini olan 128 TWh'tan \%40 daha fazla olarak $180 \mathrm{TWh}$ olarak hesaplanabilecektir (URL-3, 2018; Buttanr1, 2006).

Türkiye'de de KÖS çalışmaları çok yoğun bir şekilde devam etmektedir. Bu konuda devlet yatırımlarının yanında, elektrik alım garantisi verilen özel sektör de büyük yatırımlar yapmaktadır. Ülkemizde 2017 tarihi itibarıla, hidroelektrik tesislerin durumu Tablo 3'de görülmektedir (Buttanr1, 2006; Kaygusuz, 2018; URL-4, 2018)

Tablo 2. Hidroelektrik potansiyelin proje aşamalarına göre dağılımı (URL-4, 2018)

\begin{tabular}{lllll}
\hline HES Aşaması & HES & Toplam Kurulu & Ortalama Yillık & $\begin{array}{l}\text { Toplamdaki } \\
\text { Payı (\%) }\end{array}$ \\
& Adedi & Kapasite (MW) & Üretim $(\mathrm{GWh} / \mathrm{y} 1)$ & Pa.4 \\
\hline İşletmede & 623 & 27377 & 96026 & 8.5 \\
İnşa Halinde & 59 & 5231 & 15373 & 38.1 \\
İşaata Henüz Başlanmayan & 1116 & 22383 & 68601 & 100 \\
Toplam & 1798 & 54991 & 180000 & \\
\hline
\end{tabular}

Devlet Su İșleri (DSİ) Genel Müdürlüğü'nce hazırlanan faaliyet raporunda, 2017 y1li sonu itibariyle Türkiye'de hali hazırda işletmede bulunan 623 adet hidroelektrik santralinin toplam kurulu gücü 27,377 MW olup, y1llık ortalama üretimi ise $96026 \mathrm{GWh}$ 'tr. Bu miktar ülkede geliştirilen 180,000 GWh y1llk hidrolik potansiyelin yaklaşık \%53,4'üne karş1lı 
gelmektedir. Diğer taraftan, 5,231 MW bir kurulu güç elde edilecek ve toplam potansiyeli $\% 8,5$ olan $15,373 \mathrm{GWh} / \mathrm{y}$ ll'llk üretim kapasitesine sahip olacak 59 adet HES halen inşa halinde bulunmaktadır. Türkiye, geriye kalan 68,601 $\mathrm{GWh} / \mathrm{yll}$ 'lık hidrolik potansiyelini kullanarak 22,383 MW kurulu güç elde edebilmek için ileride 1116 HES yapılacaktır. Böylelikle Türkiye'nin toplam hidroelektrik santral sayıs1 1798 'e, kurulu gücü 54,991 MW'a ve nihayetinde ülkenin hidrolik kapasitesi olan y1llı toplam 180,000 GWh'lık bir üretim hedefine ulaşması sağlanacaktır (Aksungur, 2011). Hidroelektrik santral imalatları sırasında aktarılan bütçeler ve kullanılan kredilerin bir maliyeti vardır ve kısa süre içerisinde elde edilecek fayda ile maliyetler finanse edilmelidir. Türkiye'de hidroelektrik santrallerinde kapasite faktörü ortalaması \%37 olup bu oran dünyada \%44 tür (URL-5, 2018)

$\mathrm{Bu}$ çalışmada küçük hidrolik santrallerin Türkiye elektrik üretimine katkısı hakkında bilgi verildikten sonra, hidroelektrik santrallerin planlanmasinda ana etmenler olan nominal tepe gücün kurulu güce oranı ile elde edilen ve diğer santrallerle kiyaslamada belirleyici rollerden biri olan Kapasite Faktörü Analizi Giresun özelinde yapılmıştır.

\section{Materyal ve Metot}

Çalışmada, Devlet Su İşleri Genel Müdürlüğü'ne bağlı Trabzon Bölge Müdürlügü̆'nden alınan ve Giresun İli'nde bulunan küçük hidroelektrik santrallerin (1 MW-15 MW) kurulu güç ve toplam enerji verileri kullanılmıştır. Verilerin değerlendirilmesinde hidroelektrik santrallerin kıyaslanmasında belirleyici parametrelerden biri olan kapasite faktöründen yararlanılmıştır. Bu bağlamda aşağıda Kapasite Faktörü eşitliği verilmiştir.

Kapasite Faktörü (\%) $=\frac{\left(\text { Toplam Enerji } \frac{(\mathrm{MWh})}{365} \text { Gün }\right)}{(\text { Kurulu Güç (MW) } 24 \text { Saat })}$

Hesaplanan Maliyet Analizine göre 1 MW gücünde ve bu gücü üretebilecek debi ve hıza sahip bir akarsuyun üzerine kurulan rezervuar (biriktirme haznesi) alanı on beş kilometrekarenin altında olan hidroelektrik üretim tesisi $(\mathrm{KÖH})$ Enerji Santraline göre hesaplanmıştır. $\mathrm{Bu}$ hesaplamalarda aşağıda sıralanan veriler esas alınmıştır:

-İlk Yatırım Bedeli: 1,250 €/kW (Yatırım Bedeli ve Lisans Bedelleri dâhildir)

-Günümüzde türbin fiyatı $750-1,200 € / \mathrm{kW}$ 'tır.

Ortalama $1,000 €$ alınmıştır
-Montaj bedeli + diğer masraflar (debi analizi, projelendirme v.s) yaklaşı $\% 25: 250 € / \mathrm{kW}$

-Toplam kurulum bedeli: 1,250 €/kW olarak alınmıştır.

-Elektriğin Devlete Satış Bedeli: 0.055 Euro/kWh (2018 B.F.)

\section{Bulgular}

Materyal-Metot 'da verilen bilgiler kullanılarak; 1 MW gücünde bir küçük hidroelektrik santralin toplam ilk yatırım bedeli: $1,250 € / \mathrm{kW} * 1000$ $\mathrm{kW}=1,250,000$ Euro olarak hesaplanmıştır. Tablo 3 'ün dördüncü sütununda her bir hidroelektrik santralin yatırım bedeli toplam kurulu güç ile $1,250,000$ Euro çarpılarak elde edilmiştir. Hidroelektrik santralde üretilen elektriğin yenilenebilir enerji kaynağ durumunda satış bedeli: 0.055 Euro/kWh'tır. İşletme maliyeti ise yaklaşı olarak 0.010 Euro/kWh'tir. Üretilen elektriğin kâr1: 0.055$0.010=0.045$ Euro/kWh bu da (45 Euro/MWh) olur. $\mathrm{Bu}$ bedel yıllık toplam enerji miktarı ile çarpılarak Tablo 3'ün beşinci sütununda sunulmuştur. Sütun altıda belirtilen geri dönüş süresi ise santral bedelinin yıllık kara bölümü ile elde edilmiştir. Tablo 3 'ün yedinci sütununda ise enerji maliyeti, santral bedelinin toplam enerjiye bölünmesi ile elde edilmiştir.

Tüm yatırım araçlarında olduğu gibi enerji yatırımlarındaki amaç yapılan yatırımın en kısa sürede geri dönmesi ve yatırımcıyı kâra geçirmesidir. Yatırımlar yapılırken kullanılan krediler de göz önüne alındığında geri dönüş süresinin önemi daha da artmaktadır. Hidroelektrik santrallerin teknik özellikleri ve performansları göz önüne alındığında santrallerin kapasite faktörlerinin yüksek kurulu güce sahip bölgelerden doğrudan etkilendiği görülmektedir. Uygulamamizda Giresun İli'nde bulunan ve planlamas1 yapılan KHS'lerin listesi Tablo 3'te sunulmuştur. $\mathrm{Bu}$ santrallerin depolamasız olması ve diğer teknik unsurlarının da benzer olması nedeni ile bu santralleri kendi içlerinde kapasite faktörü esas alınarak siniflandırılır. Bu sinıflandırmada kapasite faktör ortalaması olup 37.77 değerinin yaklaşık Türkiye ortalamasında olduğu, ortalama enerji maliyetinin 40.17 $(€ / \mathrm{KWh})$ olduğu, yatırımların ortalama geri dönüş süresinin de 8,94 y1l olduğu hesaplanmıştır. Tablo 3'deki veriler kullanılarak Şekil 3 elde edilmiş olup Giresun' daki küçük HES yatırımlarının geri dönüş süresi ile kapasite faktörleri arasındaki bağlantıyı gösterir ilişki ortaya çıkarılmıştır. Şekil 3 santrallerin kapasite faktörleri artınca yatırımın geri dönüş süresinin azaldığını ortaya koymuştur. 
$\mathrm{Bu}$ çalışmadaki amaç, Giresun İli'nde yapılacak HES imalatlarında imalat önceliğinin yüksek kapasite faktörüne sahip HES'lere verilerek yatırımın geri dönüş süresinin kısaltılması ile kısıtlı bütçesi olan yatırımcı ve ülke ekonomisine daha fazla katkının sağlanmasıdır.

Tablo 3. Giresun İlindeki küçük HES'lere ait teknik veriler ve kapasite faktörü hesab1

\begin{tabular}{|c|c|c|c|c|c|c|c|}
\hline $\begin{array}{l}\text { Hidroelektrik } \\
\text { Santralın Adı }\end{array}$ & $\begin{array}{l}\text { Kurulu } \\
\text { Güç } \\
\text { (MW) }\end{array}$ & $\begin{array}{l}\text { Toplam } \\
\text { Enerji } \\
\text { (MWh) }\end{array}$ & $\begin{array}{l}\text { Santral } \\
\text { Bedeli } \\
(€)\end{array}$ & $\begin{array}{l}\text { Y1ll1k } \\
\text { Kar } \\
(€)\end{array}$ & $\begin{array}{l}\text { Geri Dönüş } \\
\text { Süresi } \\
\text { (Yil) }\end{array}$ & $\begin{array}{l}\text { Enerji } \\
\text { Maliyeti } \\
(€ / K W h)\end{array}$ & $\begin{array}{l}\text { Kapasite } \\
\text { Faktörü } \\
(\%)\end{array}$ \\
\hline Moran & 5.75 & 11110.00 & 7187500 & 499950 & 14.38 & 0.65 & 22.06 \\
\hline Akköy II & 7.33 & 15100.00 & 9162250 & 679500 & 13.48 & 0.60 & 23.52 \\
\hline Güce & 10.57 & 25270.00 & 14212500 & 1137150 & 11.62 & 0.52 & 27.29 \\
\hline Yiğit & 7.54 & 19114.00 & 9425000 & 860130 & 10.96 & 0.49 & 28.94 \\
\hline Serhat & 9.10 & 24840.00 & 11375000 & 1117800 & 10.18 & 0.46 & 31.16 \\
\hline Çalıkobası & 8.28 & 22920.00 & 10350000 & 1031400 & 10.04 & 0.45 & 31.60 \\
\hline Tokmadin & 3.57 & 10160.00 & 4462500 & 457200 & 9.76 & 0.44 & 32.49 \\
\hline Delisava & 4.88 & 14110.00 & 6100000 & 634950 & 9.61 & 0.43 & 33.01 \\
\hline Merek & 9.18 & 26650.00 & 11475000 & 1199250 & 9.57 & 0.43 & 33.14 \\
\hline Yüce & 10.57 & 30750.00 & 13212500 & 1383750 & 9.55 & 0.43 & 33.22 \\
\hline Gelen & 6.56 & 19300.00 & 8200000 & 868500 & 9.44 & 0.42 & 33.59 \\
\hline Soğukpınar & 8.90 & 28100.00 & 11125000 & 1264500 & 8.80 & 0.40 & 36.04 \\
\hline Gecür & 3.23 & 10200.00 & 4037500 & 459000 & 8.79 & 0.40 & 36.08 \\
\hline Yumruktepe & 13.68 & 43720.00 & 17100000 & 1967400 & 8.69 & 0.39 & 36.49 \\
\hline Ekere & 4.18 & 13620.00 & 5225000 & 612900 & 8.53 & 0.38 & 37.23 \\
\hline Kızılev & 11.49 & 37950.00 & 14362500 & 1707750 & 8.41 & 0.38 & 37.70 \\
\hline Üçgen 2 & 10.22 & 33815.00 & 12775000 & 1521675 & 8.40 & 0.38 & 37.79 \\
\hline Arpacık & 3.77 & 12520.00 & 4712500 & 563400 & 8.36 & 0.38 & 37.91 \\
\hline Telli I & 9.10 & 30270.00 & 11375000 & 1362150 & 8.35 & 0.38 & 37.97 \\
\hline İlimsu & 4.57 & 15300.00 & 57125000 & 688500 & 8.30 & 0.37 & 38.22 \\
\hline Vanazit & 2.66 & 9120.00 & 3325000 & 410400 & 8.10 & 0.36 & 39.14 \\
\hline Kanat & 13.30 & 46000.00 & 16625000 & 2070000 & 8.03 & 0.36 & 39.48 \\
\hline Köprübaşı & 5.70 & 20200.00 & 7125000 & 909000 & 7.84 & 0.35 & 40.46 \\
\hline Karaca & 3.01 & 19978.00 & 3762500 & 494010 & 7.62 & 0.34 & 41.61 \\
\hline Çanakçı I & 6.00 & 22720.00 & 7500000 & 1022400 & 7.34 & 0.33 & 43.23 \\
\hline Adadağı & 4.70 & 18198.00 & 5875000 & 818910 & 7.17 & 0.32 & 44.20 \\
\hline Çay Reg. & 10.05 & 39980.00 & 12562500 & 1799100 & 6.98 & 0.31 & 45.41 \\
\hline Akköy & 14.07 & 57510.00 & 17587500 & 2587950 & 6.80 & 0.31 & 46.66 \\
\hline Kiran & 9.74 & 40690.00 & 12175000 & 1831050 & 6.65 & 0.30 & 47.69 \\
\hline \multirow[t]{2}{*}{ Kahraman } & 1.52 & 6650.00 & 1900000 & 299250 & 6.35 & 0.29 & 49.91 \\
\hline & & & & Ortalama & 8.94 & 40.17 & 37.77 \\
\hline
\end{tabular}




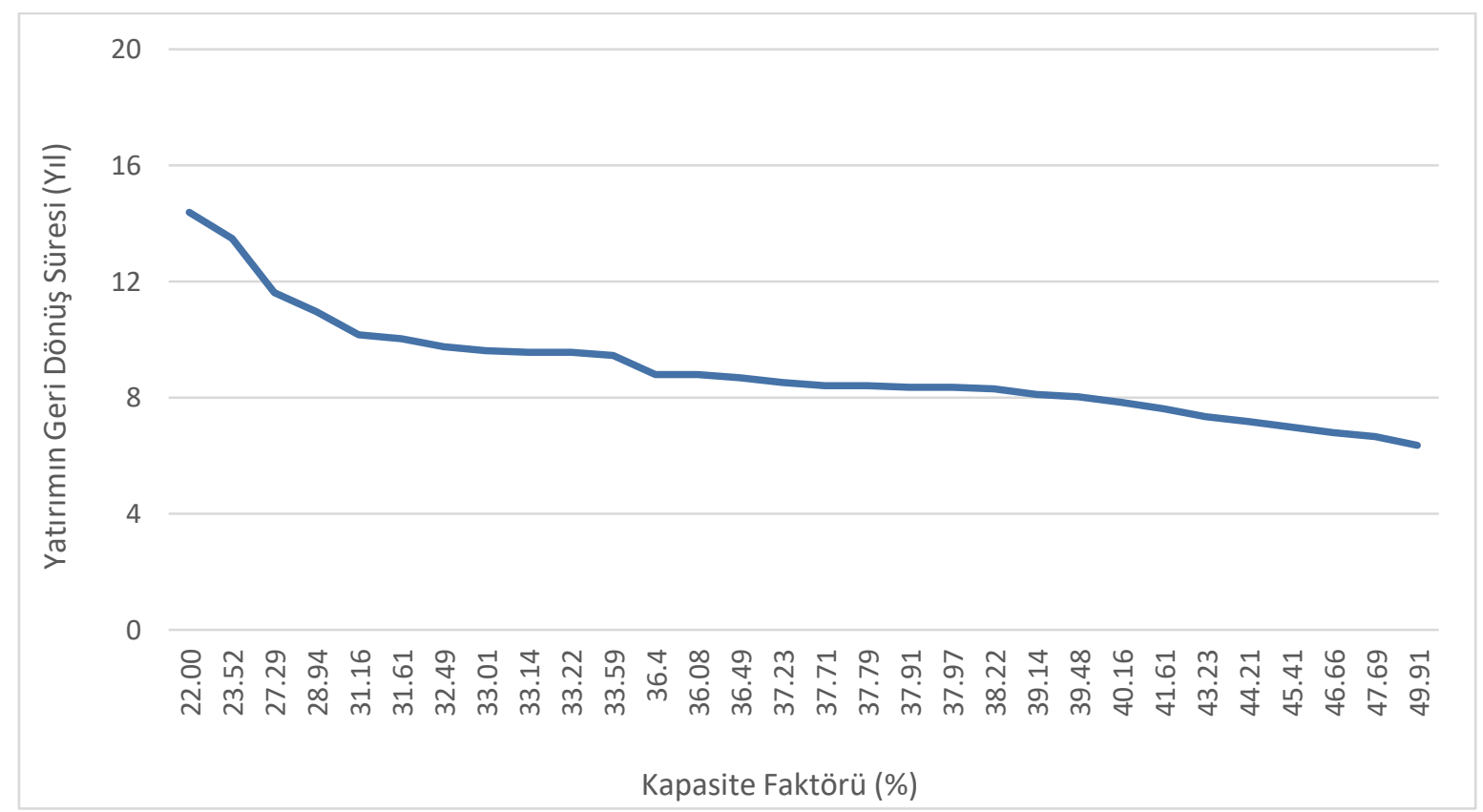

Şekil 3. Yatırım geri dönüşs süresinin kapasite faktörleri ile karşılaştırılması

\section{Sonuçlar ve Tartışma}

Ülkemiz özellikle fosil kökenli enerji kaynakları bakımından oldukça fakir olup, 2016 yılında kullandığ1 toplam enerjinin \%76'sını dişarıdan ithal etmiş ve bunun için 54,6 milyar dolarlık bir ödeme yapmıştır. Bu durumun önüne geçmek için temiz ve çevre dostu olarak bilinen yenilenebilir enerji kaynaklarının değerlendirilmesine daha büyük önem verilmelidir. Dışa bağımlılığı azaltarak güvenli, sürdürülebilir bir enerji yönetimi ilkesi benimsenmelidir. Ancak, enerji üretim tesisleri planlanırken ve yapım aşamalarında, tesisin kurulacağı alanlardaki tabiat florasının devamlılığ su ihtiyaçlarının karşılanabilmesi de düşünülmelidir. Bunun içinde özellikle suyun yönü ve yeri değiştirilerek kurulacak nehir tipi hidroelektrik santrallerin planlamalarında, akarsu yatağına bırakılacak kuyruk suyunun miktarının doğal yaşam döngüsünü devam ettirecek miktarda olmasına azami özen gösterilmelidir.

Günümüzde ticari rekabetin artmasına paralel olarak küresel piyasalarda meydana gelen dalgalı ekonomik veriler enerji fiyatlarını yukarı çekmektedir. $\mathrm{Bu}$ durum, özellikle son yillarda enerjiye olan talebi y1ll1k ortalama $\% 8$ artan ülkemizde, dışa bağımlılığ 1 azaltmak ve enerjiye dayalı döviz kaybını en aza indirmek için yapılan çalışmalarda pek çok açıdan faydalı olan yerli kaynakların küçük hidroelektrik santrallerine (KHS) daha büyük önem verilmesine neden olmuştur. KHS'ler kapasiteleri $(<10 \quad \mathrm{MW})$ olduğundan, ilk yatırım maliyetleri, işletme ve bakım giderleri barajlara göre çok daha hesaplıdır. $\mathrm{Bu}$ durum birçok yatırımcının dikkatini çekmiş, devletin verdiği enerji alım garantileri de (KHS) daha önce hiç santral yapmamış yatırımcıları da bu kulvara itmiştir. Ancak KHS inşaatları konusunda daha önce deneyimi bulunmayan yatırımciların projelerin fizibilite, tasarım ve inşaat aşamalarında gerekli teknik çalışmaları çok hassas bir şekilde yerine getirmeli, yapılacak imalatlar esnasında santralin en verimli bir şekil enerji üretimi temin edilirken çevre hassasiyeti de göz ardı edilmemelidir. Teknik ve çevresel faktörleri dikkate alarak planlanan küçük hidrolik santraller ülke ekonomisine önemli ölçüde katk1 sağlayabilirler. Sonuç olarak:

- Kurulum alanı küçük birikme haznesiz HES'ler giderek önem kazanmaktadırlar.

- Doğru projelendirilen HES'ler nehirlerin biyolojik ve morfodinamik sürekliliğini kesintiye uğratmazlar.

- İlk yatırım ve işletme maliyetlerinin düşüklügü nedeniyle HES'lerin birim enerji maliyetleri çok düşüktür,

- HES'lerde yakıt kullanılmadığından $\mathrm{CO}_{2}$ salınımı yoktur,

- Türkiye'de enerji ithalat giderlerinin azaltılması için HES'lerin yapımına ağırlık verilmiştir.

- HES imalatları yapılırken vadi planlamaları dahilinde belirlenen HES'lerin enerji üretim miktarlarının kapasite faktörleri ve kurulu güç miktarları ile değerlendirilerek en kârlı olanına yapım önceliği verilmelidir. 
Türkiye'nin brüt yüzeysel su potansiyeli yıllık yaklaşık $186 \times 10^{9} \mathrm{~m}^{3}$ kadardır. Bu potansiyelin yaklaşık $126 \times 10^{9} \mathrm{~m}^{3}$ ü enerji üretiminde kullanılabilecek durumdadır. 2017 yılı verilerine göre bunun yalnıza \%35'i değerlendirilebilmektedir. Ancak, ülkemizin mevcut su potansiyeli, küresel iklim değişiklikleri, ekonomik ve teknik ilerlemeler dikkate alınarak güncellenmelidir.

\section{Kaynaklar}

Aksungur, M., Ak, O., ÖzdemiR, A., 2011. The effect on aquatic ecosystems of river type hydroelectric power plants: the case of TrabzonTurkey, Journal of FisheriesSciences.com, 5(1), 79-92.

Buttanrı, B., 2006. Türkiye'de Küçük Hidroelektrik Santrallerin Tarihsel Gelişimi ve Bugünkü Durum, Yüksek Lisans Tezi, İstanbul Teknik Üniversitesi Fen Bilimleri Enstitüsü, 234s.

DSİ, 2017. 2017 Y1lı Faaliyet Raporu, Ankara, Türkiye.

ETKB, 2017. Dünya ve Türkiye Enerji ve Tabii Kaynaklar Görünümü, Ankara, Türkiye.

Karagöl, E.T. Kaya, S. ve Koç, Y.E., 2016. 2016'da Türkiye, SETA Siyaset, Ekonomi ve Toplum Araştırmaları Vakfı Yayınları, 253-264, İstanbul, Türkiye.
Kaygusuz, K., 2018. Small hydropower potential and utilization in Turkey, Journal of Engineering Research and Applied Science, 7(1), 791-798.

Koralay, N., Kara, O., Kezık, U., 2018. Effects of runof-the-river hydropower plants on the surface water quality in the Solakli stream watershed, Northeastern Turkey, Water and Environment Journal, 32(3), 412-421.

URL-1, http://www.enerji.gov.tr/tr-TR/Enerji-ve-TabiiKaynaklar-Gorunumleri. 8 Ekim 2018.

URL-2,

http://www.emo.org.tr/ekler/da44881c9619855_ ek.pdf. 8 Mayıs 2018.

URL-3, http://ressiad.org.tr/makaleler.php?ID=20. 18 Temmuz 2018.

URL-4,

https://www.mmo.org.tr/sites/default/files/Enerj iGorunumu2018_2_0.pdf. 8 Mayıs 2018.

URL-5, www.temsan.gov.tr. 8 Mayıs 2018.

Ürker, O. ve Çobanoğlu, N., 2017. Türkiye'de hidroelektrik santraller'in durumu (HES'ler) ve çevre politikaları bağlamında değerlendirilmesi, Ankara Üniversitesi Sosyal Bilimler Dergisi, $3(2), 65-88$.

Yuksel, I., 2013. Renewable energy status of electricity generation and future prospect hydropower in Turkey, Renewable Energy, 50, 1037-1043. 